\title{
Management of chrysanthemum white rust an intercepted quarantine disease for India, under green house condition
}

\author{
B.G. BARHATE*, N.A. MUSMADE AND J.B. BAHIRAT
}

Department of Plant Pathology and Agricultural Microbiology, Mahatma Phule Krishi Vidyapeeth, Rahuri, AHMEDNAGAR (M.S.) INDIA

\section{ARITCLE INFO}

Received : 02.02 .2015

Revised : 21.02.2015

Accepted : 09.03.2015

\section{KEY WORDS :}

Chrysanthemum, CWR, Quarantine, Climate change, Fungicides, Varietal screening
*Corresponding author:

Email: bgbarhate@gmail.com

\begin{abstract}
The symptoms produced by the pathogen was most commonly appeared on young leaves and flower bract. Initially it shows numerous, light green to yellow spot, slightly raised appear on the upper surface of leaf. These spot become brown and necrotic with age. The maximum incidence and intensity of chrysanthemum white rust disease was observed at $25-27^{\circ} \mathrm{C}$ temperature and high relative humidity of 85-90 per cent in protected condition while in case of non protected condition no infection occurred due to high temperature and low humidity. The curative spray of propiconazole was most effective in controlling the CWR, followed by hexaconezole + mancozeb, tridemefon, captan + hexaconezol whereas, other fungicides viz., carbendazim, copper oxychloride, zineb were least effective against the chrysanthemum white rust. Among the 14 varieties screened under artificial epiphytotics in green house, no one was found to be resistant to white rust of chrysanthemum, while seven varieties were moderately resistant to CWR and these are PN-1 (29.33\%) PN-138 (30.33\%), PN-6 (29.67 \%), D-21 mix (25.00\%), New Dagger (30.00\%), D-No-9 (23.33\%), and PN-16 (30.67\%), five were moderately susceptible. One was susceptible, and remaining one was highly susceptible to chrysanthemum white rust.
\end{abstract}

How to view point the article : Barhate, B.G., Musmade, N.A. and Bahirat, J.B. (2015). Management of chrysanthemum white rust an intercepted quarantine disease for India, under green house condition. Internat. J. Plant Protec., 8(1) : 134-137. 